\title{
Avanços metodológicos na avaliação da qualidade da forragem conservada
}

\author{
Clóves Cabreira Jobim', Luiz Gustavo Nussio², \\ Ricardo Andrade Reis ${ }^{3}$, Patrick Schmidt ${ }^{4}$
}

\author{
1 - Prof. do Departamento de Zootecnia da UEM, Maringá,PR. ccjobim@uem.br \\ 2 - Prof. do Departamento de Zootecnia da USP/ESALO, Piracicaba,SP. nussio@esalq.usp.br \\ 3 - Prof. do Departamento de Zootecnia da UNESP, Jaboticabal, SP. rareis@fcav.unesp.br \\ 4 - Prof. do Campus Experimental de Registro/UNESP, Registro, SP. patrick@ registro.unesp.br
}

RESUMO - A avaliação correta do valor nutricional da forragem passa obrigatoriamente por emprego de metodologias adequadas. A qualidade da forragem depende dos produtos da fermentação, no caso da silagem, ou da magnitude das perdas de compostos solúveis e atuação de microrganismos no caso do feno. A abordagem do tema: Avanços metodológicos na avaliação da qualidade da forragem conservada, na 44a Reunião Anual da Sociedade Brasileira de Zootecnia, tem como objetivo destacar as principais metodologias empregadas na avaliação específica de forragens conservadas, adicionais às avaliações tradicionais de composição químico-bromatológica desses volumosos, e colocar em discussão a necessidade de padronização de procedimentos analíticos. Assim, a revisão prioriza a descrição e sistematização de métodos físicos e químicos importantes para serem implementados na avaliação de forragens conservadas, na tentativa de homogeneizar tais procedimentos. Os recursos metodológicos disponíveis atualmente permitem não somente quantificar, mas também qualificar perdas ocorridas no processo de conservação, exposição aeróbia e oferta dos volumosos aos animais. Esse fato sugere que a adoção de estratégias de manejo dessas forragens deverá, preferencialmente, ser acompanhada de avaliação de perdas integradas no processo.

Palavras-chave: análises físicas, ensilagem, fenação, microrganismos, perdas

\section{Methodological advances in evaluation of preserved forage quality}

\begin{abstract}
The suitable evaluation of nutritional value of forages depends on the adoption of appropriate methodologies. Forage quality is highly dependent of fermentation products, in case of silage, and the losses of soluble compounds and microorganisms activity in the case of hay. The theme "Methodological advances in evaluation of preserved forage quality" at the $44^{\text {th }}$ Annual Meeting of Brazilian Society of Animal Science has as main goals to highlight the more useful and particular methodological procedures for conserved forages and additional to the standard chemical analysis.. Analytical procedures for preserved forage should suffer a standardization to permit comparisons of results obtained by the world wide laboratories. This review brings to discussion the description and systematization of important physical and chemical methods to be implemented in preserved forage evaluation. The methodological procedures available permit not only quantify, but also permit qualify the losses occurred during preservation process and across the aerobic exposition of the roughage source during feed out. It suggests that the adoption of any management strategies for conserved forages may depend on an evaluation accordingly fit to the losses observed in the overall process.
\end{abstract}

Key Words: ensilage, haymaking, losses, microorganisms, physical analyses

\section{Introdução}

Em qualquer sistema de produção animal a qualidade dos alimentos que compõem a ração é de fundamental importância na busca da eficiência.
Destaca-se que, na maioria das explorações, os gastos com alimentação animal representam a maior parte dos custos de produção. Diante disso, o emprego de tecnologia adequada na produção de alimentos é fator primordial. Especialmente as 
forragens conservadas como feno ou silagem podem ter seu valor alimentício bastante alterado em razão dos procedimentos adotados para a sua produção e conservação, e dos fenômenos bioquímicos e microbiológicos que ocorrem no processo. Em geral, a resposta do animal à silagem é dependente do padrão de fermentação que por sua vez afeta a forma e a concentração dos nutrientes e a ingestão. Da mesma forma, as alterações que ocorrem durante a secagem, recolhimento e armazenamento do feno, exercem influência marcante na composição química, ingestão e digestibilidade da forragem.

Em razão disso, torna-se imprescindível a avaliação da qualidade da silagem ou do feno para adequada formulação da ração animal. Portanto, deve-se ter presente que Qualidade da forragem é uma expressão utilizada como referência ao valor nutritivo da massa de forragem em interação com o consumo efetuado pelo animal e com o potencial de desempenho do animal. $O$ desenvolvimento de técnicas para avaliar a qualidade de silagens evoluiu em conjunto com vários processos como: desenvolvimento de equipamentos de colheita e processamento; desenvolvimento de métodos e estruturas de armazenamento; variação nas necessidades das rações dos animais para aumento do potencial de produção. Já em relação ao feno, especialmente no Brasil, constatase que são raros os trabalhos que contemplam avaliações relativas às alterações que ocorrem durante o processo de fenação. A maioria dos estudos com feno é relacionada a avaliações do valor nutricional, sem maiores preocupações com as perdas na qualidade da forragem durante a confecção e armazenagem. Assim, são poucos os avanços metodológicos relativos à avaliação de forragens desidratadas.

Novos procedimentos metodológicos para auxiliar na avaliação de silagens têm sido empregados em vários países do mundo. A orientação da comunidade científica internacional tem sido priorizada no sentido de explorar métodos de avaliação física como forma complementar para interpretar resultados de avaliação química tradicional. No Brasil, os métodos químicos tradicionais para avaliação de silagens foram sistematizados por Silva \& Queiroz (2002) e recentemente alguns deles revistos por Campos et al. (2004).

A presente revisão vem concentrar esforços na

๑ 2007 Sociedade Brasileira de Zootecnia descrição, sistematização e tentativa de homogeneizar alguns métodos físicos importantes para serem implementados na avaliação de forragens tropicais conservadas.

\section{Amostragem}

O processo de amostragem pode ter grande influência sobre a avaliação da qualidade dos alimentos, especialmente de silagens e fenos, dado os efeitos da tecnologia empregada na confecção da forragem conservada. Diante disso, fica evidente que a acurácia de uma análise da qualidade da forragem começa pela amostragem criteriosa do material a ser avaliado. Cherney \& Cherney (2003) definem acurácia na amostragem como sendo a habilidade de coletar uma amostra que represente o alimento.

Uma forma de se avaliar o efeito do processo de ensilagem e de fenação sobre a qualidade da forragem é o de comparar a composição químicobromatológica antes e após a confecção da silagem ou feno. Antes da ensilagem ou fenação a forragem pode ser amostrada no campo ou após o corte. No campo a amostragem pode ser influenciada por fatores intrínsecos da espécie, como porte da planta e presença de grãos. Na ensilagem de plantas de porte alto e com presença de grãos como o milho e o sorgo, segundo Cherney \& Cherney (2003), há dificuldade de amostragem em razão da variabilidade existente entre plantas. Segundo os autores é difícil manter a acurácia da relação grão/colmo/ folha quando um grande número de plantas de milho são cortadas e sub-amostradas.

Também na amostragem da forragem picada, antes da ensilagem, deve-se ter cuidado, pois o transporte no vagão ou carreta tende a separar as partículas por peso e tamanho. Colmo, folhas e grãos podem ser segregados levando a erros de amostragem. Esse problema pode ser reduzido fazendose várias sub-amostragens durante o descarregamento do vagão para compor a amostra principal.

Especialmente em silagens, onde pode haver diferenças significativas na composição química da massa de forragem em relação à localização da amostragem no painel do silo, a retirada de amostra deve ser criteriosa. Deve-se considerar que, principalmente nas áreas periféricas do silo, normalmente ocorrem maior atividade microbiológica com alterações relevantes na composição da forragem. Assim sendo, recomenda-se que sejam tomadas 
amostras em pontos que contemplem toda a superfície do painel. Posteriormente, essas amostras formarão amostra compostas para as análises desejadas. Segundo trabalho de Haslemore \& Holland (1981) citado por Cherney \& Cherney (2003) o número de amostras adequado é variável em função do parâmetro a ser avaliado. Por exemplo, a determinação do $\mathrm{pH}$ e da digestibilidade requerem um menor número de amostras em relação à determinação de carboidratos solúveis, da matéria seca ou de produtos da fermentação. Já a amostragem em silos experimentais não é problema porque a amostra é toda processada, dependendo do volume do silo.

A amostragem em fardos de feno é mais simples e deve seguir o critério de representatividade do material, com amostragens em vários fardos. É importante que o fardo seja aberto para que a amostra contemple a forragem do interior do fardo. Posteriormente, pode-se trabalhar com amostras compostas para as análises laboratoriais.

\section{Análises físicas de forragens conservadas}

Existem várias formas de se avaliar a qualidade de um alimento conservado (olfato, análises químicas e microbiológicas, desempenho dos animais), sendo que o aspecto físico, principalmente a massa específica (ME) da forragem e o tamanho médio de partículas devem ser priorizados nessa avaliação. Esses fatores podem ser críticos, especialmente no processo de ensilagem.

O termo densidade, embora internacionalmente adotado, é indevidamente usado para definir a massa específica ( $\mathrm{kg}$ de $\mathrm{MV}$ ou $\mathrm{MS} / \mathrm{m}^{3}$ ) de uma silagem armazenada. A densidade de um corpo é a relação entre as massas específicas do corpo e de um líquido padrão (água), nas mesmas condições, e é adimensional (não possui unidade). A massa específica é a razão entre a massa de uma quantidade da substância e o volume por ela ocupado. Embora a questão possa parecer semântica, os valores para cada variável são diferentes. Na prática os dois termos são usados como sinônimos.

A ME é fator determinante na qualidade final do volumoso e, entre vários fatores, é determinada pelo tamanho médio de corte aplicado na planta forrageira utilizada. O tamanho médio de partículas (TMP) influencia a porosidade na massa de forragem colocada no silo (Paziani, 2004) e a resistência da planta à compactação. Da mesma forma, partículas de tamanho elevado reduzem a taxa de passagem ruminal de sólidos, reduzindo assim o consumo voluntário de MS (Heinrichs et al., 1999; Collao Saens, 2005).

Além do TMP, outros fatores como tipo de silo, carga de pressão aplicada, tempo total de compactação, espessura de camada adicionada, teor de MS da forragem, afetam a eficiência de compactação e a ME final obtida (Muck \& Holmes, 2000).

Embora não haja um valor considerado ideal para avaliação em um silo, recomenda-se ME superiores a $550 \mathrm{~kg}$ de $\mathrm{MV} / \mathrm{m}^{3}$ (Ruppel et al., 1995), e inferiores a $850 \mathrm{~kg}$ de $\mathrm{MV} / \mathrm{m}^{3}$, sendo esse alto valor obtido apenas em condições bastante favoráveis. Já Holmes \& Muck (1999) afirmam que os benefícios da compactação adequada sobre as características fermentativas e perdas em silagens de milho são obtidos com valores mínimos de $225 \mathrm{~kg}$ de $\mathrm{MS} / \mathrm{m}^{3}$. Contudo, dificilmente esses valores são observados em silagens de materiais mais úmidos, como gramíneas tropicais, embora a umidade auxilie na compactação.

Silagens confeccionadas com baixa ME apresentam maior teor de ar residual na massa, acarretando maior período de respiração (liberação de $\mathrm{CO}_{2}$ e perda de $\mathrm{MS}$ ), maior consumo de carboidratos solúveis, redução na velocidade de produção de ácidos orgânicos e maior valor final de $\mathrm{pH}$ da silagem (McDonald et al., 1991). Ainda, baixos valores de ME determinam maior porosidade e infiltração de ar no painel do silo aberto, menor estabilidade aeróbia e maiores perdas no período pós-abertura. Essas características, em conjunto, acarretam elevadas perdas de MS, redução no valor nutritivo da silagem e no consumo dos animais, com conseqüente elevação no custo da tonelada de MS e NDT. Ao ensilar forragens de alto teor de MS, como milho ou sorgo (acima de $35 \%$ ), esse quadro é agravado.

Por outro lado, o material compactado excessivamente no silo está predisposto à maior produção de efluentes, o que acarreta perdas qualitativas e quantitativas, além de reduzir o pool de carboidratos solúveis essenciais à boa fermentação. Esse processo é mais crítico em volumosos úmidos, como as gramíneas tropicais.

Assim, o técnico pode usar a avaliação dessas variáveis como indicativo inicial da qualidade conferida ao processo de ensilagem e do resultado

\footnotetext{
๑ 2007 Sociedade Brasileira de Zootecnia
} 
esperado no produto final. Vale lembrar que problemas observados nos parâmetros físicos dificilmente são solucionados depois da silagem pronta, devendo-se ater a esses aspectos na colheita e ensilagem a ser realizada no próximo ano agrícola.

Como forma de atenuar os efeitos prejudiciais de uma compactação inadequada no silo, Muck \& Holmes (2005) recomendam elevação na espessura da camada de silagem retirada diariamente. Os autores sugerem o valor de $30 \mathrm{~cm} / \mathrm{dia}$ como forma de minimizar as perdas no painel do silo.

\section{Metodologia para avaliação do tamanho médio de partículas}

Existem várias formas de se determinar o tamanho médio de partículas de um alimento volumoso. Basicamente, os métodos disponíveis baseiam-se na estratificação de partículas em classes de tamanho definido, podendo ser os valores expressos em \% de partículas retidas em cada classe, ou tamanho médio, mediante equações de distribuição ou cálculo do valor médio ponderal.

Lammers et al. (1996) propuseram uma metodologia prática para determinação do tamanho médio de partículas de volumosos e rações completas. O método proposto pelos autores consiste em um conjunto de duas peneiras com orifícios de 19 e $8 \mathrm{~mm}$ de diâmetro e um fundo fechado que, agitados sistematicamente, segregam a amostra em três estratos diferentes (tamanhos acima de $19 \mathrm{~mm}$, entre 19 e $8 \mathrm{~mm}$ e inferiores a $8 \mathrm{~mm}$ ). $\mathrm{O}$ método foi aceito e largamente adotado nos EUA e em outros países, principalmente para determinação de tamanho de partículas de silagens de milho.

Embora efetiva, a metodologia do Penn State Particle Size Separator (Lammers et al., 1996) não contemplava as condições encontradas na grande maioria das amostras colhidas no Brasil, uma vez que o tamanho das partículas aqui avaliadas, principalmente de silagens de gramíneas, era bastante superior ao diâmetro da maior peneira. Esse fato acarretou erros de determinação no tamanho médio de partículas gerado, decorrente de dificuldades de segregação da amostra. Esse efeito foi evidenciado por Igarasi (2002), que observou que grande parte das amostras de silagens de capim estratificadas (63-91\%) ficou retida na bandeja com perfurações de $19 \mathrm{~mm}$ de diâmetro.

Dessa forma, uma adaptação a essa metodologia foi proposta por Mari \& Nussio (2002), com

${ }^{\circledR} 2007$ Sociedade Brasileira de Zootecnia a inclusão de uma terceira peneira, com orifícios de $38 \mathrm{~mm}$ de diâmetro, produzindo dois novos estratos (acima de $38 \mathrm{~mm}$ e entre 38 e $19 \mathrm{~mm}$ ). Com essa adaptação, a estratificação de amostras contendo partículas grandes foi facilitada, gerando resultados mais exatos.

Os procedimentos adaptados de Heinrichs et al. (1999) e Lammers et al. (1996) para determinação do tamanho médio de partículas são os seguintes:

- Anotar a tara de cada peneira e do fundo;

- Pesar 250 gramas de amostra de forragem fresca;

- Colocar a amostra sobre a peneira superior e iniciar a agitação sistematizada. A agitação deve ser realizada sobre uma superfície plana e lisa, e consiste em oito séries de cinco agitações vigorosas (a cada cinco agitações o conjunto de peneiras é rotacionado $90^{\circ}$ ), totalizando 40 movimentos;

- Anotar o peso de cada peneira com a forragem retida;

- Medir com régua o tamanho médio das maiores partículas retidas na peneira superior e das menores partículas retidas na peneira fechada (fundo).

O cálculo da porcentagem de partículas retidas em cada peneira é realizado de forma direta, considerando o somatório dos pesos da fração retida em cada peneira, descontando-se a tara da peneira. O cálculo ponderal do tamanho médio das partículas é dado pelo tamanho médio das partículas retidas em cada peneira e o percentual de retenção em relação ao peso total da amostra estratificada.

Supondo-se que o tamanho das maiores partículas retidas na peneira superior seja de $80 \mathrm{~mm}$, e as menores partículas retidas no fundo apresentem 1 $\mathrm{mm}$ de comprimento, e que as porcentagens retidas nas peneiras de $38 \mathrm{~mm}, 19 \mathrm{~mm}, 8 \mathrm{~mm}$ e fundo sejam de $5,35,40$ e $20 \%$, respectivamente, o tamanho médio de partículas é dado por:

$$
\begin{aligned}
& \mathrm{TMP}=\{[(80+38) / 2] * 0,05\}+\{[(38+19) / \\
& \left.2]^{* 0,35}\right\}+\{[(19+8) / 2] * 0,4\}+\{[(8+1) / 2] * 0,2\} \\
& \text { TMP }=19,2 \mathrm{~mm} \text {. }
\end{aligned}
$$

Por ser dependente de agitação manual, recomenda-se que ao se empregar essa metodologia para comparação de amostras geradas em ensaios 
experimentais, o mesmo operador seja responsável pela estratificação de todas as amostras.

\section{Metodologia para avaliação de massa específica}

Várias metodologias têm sido testadas para avaliação da massa específica (ME) de silagens, em sua maioria constituídas por pesagem da massa de forragem retirada de um volume conhecido do silo, sendo os valores expressos em $\mathrm{kg}$ de MS ou $\mathrm{MV} / \mathrm{m}^{3}$.

A aplicação de métodos indiretos na avaliação da ME tem sido testada, visando facilitar operacionalmente a tomada desses dados em condições de campo. Nesse sentido, Schmel et al. (2006) vêm realizando estudos na Alemanha para desenvolver um sensor radiométrico que apresenta uma fonte emissora e receptora de radiação para ondas gama, que posicionado em equipamentos durante a ensilagem, ou no painel do silo, possa estimar a ME da silagem na camada de até $30 \mathrm{~cm}$ de distância do sensor cilíndrico.

Outra possibilidade testada é o método com base na ressonância em microondas que atua sobre as propriedades dipolares da molécula de água presente na massa e sua ressonância eletromagnética. Esse processo permite estimar o conteúdo de umidade e ME separadamente, mas o material a ser avaliado deve estar em contato direto com o sensor. Um terceiro método explorado é o sistema de georadar, utilizado também para estimar a ME de solos, com base em um radar de penetração que propaga ondas eletromagnéticas de alta frequiência e tem a vantagem de precisar de contato direto com a massa ensilada. A sugestão dos autores para obter medidas de densidade em tempo real seria de adaptar uma roda suspensa contendo sensores que, deslizando sobre a superfície da massa ensilada durante a compactação, enviaria sinais para um painel de controle, dando ao operador valores reais de densidade plotados contra valores de densidade alvo, permitindo a tomada de decisão em tempo real. Contudo, os métodos indiretos ainda estão em desenvolvimento e dependem de rigorosa calibração para elevar exatidão dos dados obtidos.

Para avaliação da ME de silagens de milho e gramíneas em 168 silos, Holmes \& Muck (1999) utilizaram um amostrador cilíndrico de $5 \mathrm{~cm}$ de diâmetro, retirando amostras em diversos pontos do painel do silo. Schmidt (2006) avaliou a ME de silagens de cana-de-açúcar armazenadas em silo-bolsa, utilizando um tubo de PVC com 19,6 $\mathrm{cm}$ de diâmetro e $30 \mathrm{~cm}$ de comprimento úteis $\left(0,021 \mathrm{~m}^{3}\right)$, com bordo cortante serrilhado, introduzido na massa ensilada por meio de rotação, buscando retirar a massa de forragem sem exercer deformação ou alteração na ME desta. O autor ressalta que esse método foi adotado em virtude da dificuldade de se proceder a avaliação tradicional de ME, pela retirada de cubos, em virtude da reduzida compactação obtida nos silos tubulares.

A metodologia comumente utilizada para determinação da ME é a da retirada de cubos de área conhecida do painel do silo e recolhimento da forragem. O método adotado pela Equipe de Qualidade e Conservação de Forragens da USP/ ESALQ e descrito no trabalho de Schmidt (2006) consiste em: Marcação no painel do silo de um quadrado com lados de $30 \mathrm{~cm}$; Corte a $30 \mathrm{~cm}$ de profundidade da superfície externa do quadrado, utilizando facas ou sabre da motosserra; Retirada manual e recolhimento da forragem em sacos plásticos para posterior pesagem; Nova mensuração com régua das arestas do cubo efetivamente retirado do painel do silo.

Os valores de massa de forragem e volume do cubo retirado são extrapolados para $\mathrm{kg}$ de $\mathrm{MV} /$ $\mathrm{m}^{3}$. Após a determinação do teor de MS dessas silagens, obtêm-se a ME em termos de matéria seca.

Embora trabalhosa, essa metodologia apresenta alto grau de precisão dos valores obtidos. Contudo, deve-se considerar que, conforme discutido por Holmes \& Muck (1999), a ME varia de acordo com a posição onde a amostra é retirada no silo, devendo-se usar o mesmo padrão de amostragem (número de amostras, posição de retirada no painel do silo) ao se comparar a eficiência de compactação em diferentes casos.

\section{Condutividade elétrica}

A medida da condutividade elétrica em silagens tem sido realizada com certa freqüência em estudos no Brasil. Condutividade Elétrica (CE) é definida como a capacidade que a água possui de conduzir corrente elétrica. Este parâmetro está relacionado com a presença de íons dissolvidos na água, que

() 2007 Sociedade Brasileira de Zootecnia 
são partículas carregadas eletricamente. Assim, quanto maior for a quantidade de íons dissolvidos, maior será a CE. A determinação da CE pode ser feita pelo método eletrométrico, utilizando-se condutivímetro digital. Em silagens, a CE não expressa especificamente quais os íons que estão presentes em determinada amostra, mas pode contribuir para a mensuração das perdas de conteúdo intracelular oriundos do processamento na ensilagem. Nas pesquisas com forragens ensiladas a CE tem sido determinada conforme metodologia proposta por Kraus et al. (1997). O método é realizado com base na mensuração indireta da quantidade de líquido liberado pelo rompimento de células, resultando na avaliação dos eletrólitos dispersos na solução, oriundos do conteúdo celular extravasado. Os autores propõem que $25 \mathrm{~g}$ de amostra sejam homogeneizadas durante 1 minuto com $300 \mathrm{~mL}$ de água deionizada. Após a mistura deve ser filtrada e na solução é realizada a leitura das quantidades de eletrólitos livres com uso de condutivímetro. A medida da CE é expressa em $\mathrm{m} \mathrm{S} / \mathrm{cm}$ e fornece indicativo da magnitude do rompimento de membrana celular pelo corte e processamento da forragem.

Uma vez que a CE tem sido determinada em silagens, como mais uma variável que pode contribuir para as estimativas de perdas de conteúdo celular durante o processo de ensilagem, recomenda-se que as medidas sejam realizadas em amostras antes e após a ensilagem. Isso evitaria apenas inferências sobre os valores da CE na silagem, sem valor de referência do material antes do processo. Apesar disso, os efeitos dos produtos da fermentação sobre a CE ainda não estão devidamente esclarecidos.

\section{Determinação da atividade da água (Aw)}

Segundo Ditchfield (2000) o termo atividade da água (Aw) foi criado para denominar a água disponível para crescimento microbiano e reações que possam deteriorar os alimentos. A Aw referese a medição da concentração de solutos em água e seus efeitos sobre a atividade química da água. O valor da Aw indica o nível de água em sua forma livre nos materiais e é expresso na escala de 0 a 1,0 Aw. Considera-se o valor 0 (zero) para materiais livres de água e 1,0 para a água em sua forma líquida. Logo, a atividade de água pura é
1,0 e diminui com o aumento na concentração de solutos.

No campo da avaliação de alimentos ensilados a Aw é de grande importância para a qualidade de fermentação durante a ensilagem e para a atividade microbiológica durante a fase de utilização da silagem. De acordo com Lindgren (1999) a redução na Aw pode ter efeito sinérgico na queda do $\mathrm{pH}$, devido à tolerância das bactérias ácido láticas a condições de baixa umidade, assumindo grande importância na qualidade de fermentação de silagens.

Os microrganismos de uma forma geral são fundamentais no processo de fermentação de silagens e tem sua atividade largamente afetada pela Aw. Alguns trabalhos conduzidos no Brasil, com espécies tropicais, evidenciam valores relativamente elevados para a Aw em silagens de gramíneas. Nesse contexto, Castro et al. (2001) registraram valores de Aw entre 0,69 e 0,85 para silagem de Tifton 85. Enquanto Igarasi (2002) registrou valores de Aw superiores a 0,93 para silagem de capim-Tanzânia.

O desenvolvimento da maioria das bactérias e fungos (bolores) está restrito a valores de Aw acima de 0,90 (UFRJ, 2007), enquanto que as salmonelas precisam, por exemplo, de Aw superior a 0,92 para crescimento (Tabela 1). Garcia (2004) destaca que o limite mínimo de crescimento de fungos é de 0,78 Aw e a produção de aflatoxinas é de 0,86 Aw. Segundo McDonald et al. (1991), o crescimento de bactérias do gênero Clostridium é inibido com Aw abaixo de 0,94, enquanto que as bactérias ácido láticas são menos sensíveis. Nos estudos publicados por pesquisadores brasileiros tem-se verificado que o aumento no teor de MS de silagens de gramíneas evidencia reduções na população microbiana, especialmente de clostrideos. Em silagens de materiais emurchecidos, a baixa atividade microbiana torna-se evidente pela baixa concentração de ácidos orgânicos e conseqüente $\mathrm{pH}$ mais elevado.

As amostras de silagens para medidas da Aw devem ser mantidas resfriadas para que não haja congelamento e conseqüente rompimento de células. No Brasil, são poucos os trabalhos que têm contemplado a avaliação da atividade de água em materiais ensilados. Os principais trabalhos têm sido desenvolvidos na USP/ESALQ e a metodologia empregada é aquela descrita por Mari (2003). 
Tabela 1 - Atividade de água (Aw) mínima para crescimento e para produção de toxinas de alguns microrganismos importantes para a saúde pública e que são encontrados com freqüência em forragens conservadas.

\begin{tabular}{lcc}
\hline Microrganismo & \multicolumn{2}{c}{ Aw mínima } \\
\cline { 2 - 3 } & Crescimento & Produção de Toxina \\
\hline Clostridium botulinum & $0,93-0,97$ & $0,94-0,97$ \\
Clostridium perfringens & $0,93-0,95$ & \\
Salmonella spp. & $0,92-0,95$ & \\
Bacillus cereus & $0,93-0,95$ & \\
Staphylococcus aureus & 0,86 & 0,90 (enterotoxina A) \\
& & 0,87 (enterotoxina A) \\
Aspergillus clavus & 0,85 & 0,97 (enterotoxina B) \\
Aspergillus flavus & 0,78 & 0,99 (patulina) \\
Aspergillus ochraceus & 0,83 & 0,84 (aflatoxina) \\
Penicillium expansum & $0,83-0,85$ & 0,85 (ocratoxina) \\
Penicillium viridicatum & 0,83 & 0,99 (patulina) \\
\hline
\end{tabular}

Fonte: Adaptado de Ditchfield (2000).

Após calibração do equipamento, à temperatura ambiente, são pesadas $25 \mathrm{~g}$ de amostra fresca acondicionada em copo plástico com tampa e, por meio de um orifício na mesma, introduz-se o sensor do aparelho e anota-se a leitura da amostra. Como a Aw é dependente da temperatura, é necessário indicar sempre a temperatura referência.

Na década de sessenta, Greenhill (1964), citado por McDonald et al. (1991) propôs uma equação $(\mathrm{Aw}=1-\mathrm{c} / \mathrm{m})$ para determinar a atividade de água de forragens, sendo que a Aw é determinada em termos da pressão de vapor relativa. $\mathrm{Na}$ equação, o termo $c$ é uma constante, determinada pela somatória dos pesos das moléculas e dos íons no suco da planta, e $m$ é a umidade da amostra expressa em g de água/kg de MS da forragem. Igarasi (2002) sugeriu que gramíneas tropicais deveriam apresentar valor $c$ maior que plantas de clima temperado, possivelmente pela menor concentração de cátions trocáveis na planta. McDonald et al. (1991) sugerem valores de $c$ de 0,03 a 0,05 para alfafa e trevo. Para estimar teores de MS críticos ao desenvolvimento de leveduras na ensilagem, Nussio \& Schmidt (2004) usaram valores de $c$ de 0,08 na determinação da Aw em cana-de-açúcar. Segundo os autores, esse valor foi usado devido à alta concentração de sacarose solúvel no caldo da planta.

\section{Determinação da capacidade tampão}

A capacidade tampão (CT) em plantas forrageiras é definida como a resistência que a massa de forragem apresenta ao abaixamento do $\mathrm{pH}$. Alguns autores empregam o termo Poder Tampão, no entanto recomenda-se o uso do termo capacidade tampão em razão da própria tradução para a língua inglesa como buffering capacity. A capacidade tampão depende basicamente da composição da planta no que se refere ao teor de proteína bruta, íons inorgânicos $(\mathrm{Ca}, \mathrm{K}, \mathrm{Na})$ e combinação de ácidos orgânicos e seus sais. $\mathrm{O}$ conhecimento da CT da forragem a ser ensilada é importante, pois fornece informações em relação à velocidade de abaixamento do $\mathrm{pH}$. Segundo Cherney \& Cherney (2003) a CT da forragem a ser ensilada é um fator chave no processo de fermentação. Quando a planta apresenta alta CT a velocidade de abaixamento do pH é lenta e em conseqüência as perdas no processo de ensilagem são maiores, reduzindo a qualidade da silagem.

A metodologia empregada na determinação da CT em silagens e forragens frescas adotada pela maioria dos pesquisadores, no Brasil e no exterior, é a descrita por Playne \& McDonald (1966). A metodologia propõem a maceração de aproximadamente $15 \mathrm{~g}$ de forragem fresca ou de silagem e sua diluição em $250 \mathrm{~mL}$ de água destilada. Então é realizada a titulação para $\mathrm{pH} 3,0$ com $\mathrm{HCl}(0,1$ $\mathrm{N})$ e, posteriormente, titulado com $\mathrm{NaOH}(0,1 \mathrm{~N})$ para $\mathrm{pH}$ 6,0. O mesmo procedimento é descrito por outros autores (Bolsen et al., 1992, Lin et al., 1992). A metodologia prevê expressar a CT em meq de base requerida para elevar o $\mathrm{pH}$ de 4,0 para 6,0 para cada 100 gramas de matéria seca. No entanto, a forma de expressar a CT das for-

\footnotetext{
๑) 2007 Sociedade Brasileira de Zootecnia
} 
ragens e das silagens tem sido controversa entre os pesquisadores. Alguns expressam a CT em meq de ácido/100 g de MS, enquanto outros expressam em meq de $\mathrm{NaOH}$ requerido para elevar o $\mathrm{pH}$ de $100 \mathrm{~g}$ de MS de 4,0 para 6,0. Portanto, deve-se padronizar a forma de expressão da CT, de acordo com o previsto pela metodologia, de forma a possibilitar a correta interpretação dos dados pelo leitor.

\section{Determinação dos valores de pH}

A medida do valor de $\mathrm{pH}$ em silagens foi considerada, no passado, como um importante indicador da qualidade de fermentação, sendo inclusive possível classificar as silagens em termos de qualidade. No entanto, atualmente essa variável deve ser usada com critério para fazer inferências à qualidade de fermentação, haja vista que silagens de materiais com baixo teor de umidade (silagem de forragem emurchecida) invariavelmente apresentam valores de $\mathrm{pH}$ elevados, acima de 4,2, valor anteriormente utilizado para classificar uma silagem como de qualidade pobre. Porém, segundo Cherney \& Cherney (2003), o pH ainda permanece como um bom indicador da qualidade de fermentação em silagens com baixo teor de MS e não sendo adequado para silagens com alto teor de MS.

Segundo Lindgren (1999) na literatura internacional o pH ainda é usado como um critério de qualidade importante no julgamento da qualidade de fermentação das silagens. Contudo, o indicador mais adequado para esse fim seria utilizar a concentração de ácidos orgânicos indissociados. Alguns ácidos fracos, em sua forma indissociada, podem penetrar a membrana celular e acumularem-se no citoplasma das células. Em seguida as moléculas indissociadas se dissociam e liberam prótons que abaixam o pH levando a destruição das células. Sendo assim a acidez titulável seria um conceito mais apropriado para julgar a fermentação e com isso o conceito de $\mathrm{pKa}$ seria, de fato, mais importante que o $\mathrm{pH}$ propriamente dito. De acordo com o referido autor os ácidos são erroneamente expressos como porcentagem da matéria seca, o que não considera o potencial de preservação proporcionado pelo ácido. Esse fato pode ser facilmente exemplificado em uma silagem bem preservada com outra similar que recebeu adição de $20 \%$ de água. Essa adição

๑) 2007 Sociedade Brasileira de Zootecnia não altera a relação de ácidos orgânicos na matéria seca mas reduz a concentração desses na fase líquida, que de fato, é responsável pela ação antimicrobiana e potencial de armazenamento da forragem. Contudo, a determinação de acidez titulável proposta pelo autor mostra-se trabalhosa e demorada, quando se pretende avaliar um conjunto grande de amostras geradas em ensaio experimental.

Em relação à metodologia empregada, a maioria dos pesquisadores brasileiros têm adotado o procedimentos descrito por Silva \& Queiroz (2002), com base na diluição de nove gramas de silagem fresca em $60 \mathrm{~mL}$ de água destilada e leitura do $\mathrm{pH}$ após 30 minutos de repouso. Outro método comumente empregado para medir o $\mathrm{pH}$ em silagens é fazer a extração do suco em prensa hidráulica e realizar a medida de acidez diretamente com potenciômetro (Wilson \& Wilkins, 1972).

Para silagens com alto teor de MS, como silagem de forragem emurchecida e silagem de grãos, o uso de amostras diluídas em água deionizada tem sido adotado com freqüência. $\mathrm{O}$ método freqüentemente empregado é o descrito por Kung Jr. et al. (1984). Inicialmente é obtido um extrato aquoso com $25 \mathrm{~g}$ de amostra fresca sendo processada em liquidificador com $225 \mathrm{~mL}$ de água deionizada, por cerca de 1 minuto. $\mathrm{O}$ pH é medido em potenciômetro digital.

Em silagens de grãos de milho e de outros cereais, normalmente o $\mathrm{pH}$ é determinado segundo Phillip \& Fellner (1992). Os autores recomendam empregar $25 \mathrm{~g}$ de silagem fresca diluídas em 100 $\mathrm{mL}$ de água destilada, deixar em repouso por 1 hora antes da leitura do $\mathrm{pH}$. Outro procedimento adotado para medidas de $\mathrm{pH}$ de forragens ou silagens com alto teor de MS é macerar a amostra e adicionar água destilada. Cherney \& Cherney (2003) recomendam adicionar água numa relação forragem fresca $(\mathrm{g})$ :água $(\mathrm{mL})$ de 1:10. Posteriormente o pH é medido diretamente com uso de potenciômetro. Segundo os autores para amostras com alto teor de umidade não há necessidade de adicionar maiores quantidades de água para determinar o pH. A recomendação é adicionar $125 \mathrm{~mL}$ de água destilada fria em 50 gramas da silagem fresca e deixar em repouso por $1 \mathrm{~h}$ antes da leitura do $\mathrm{pH}$.

O procedimento recomendado por Cherney \& Cherney (2003) pode ser adotado como padrão na determinação do $\mathrm{pH}$ em silagens porque define a 
relação entre o peso da amostra e o volume de água a ser adicionado.

\section{Determinação da presença de microrganismos}

No Brasil, as análises microbiológicas em silagens e fenos ainda podem ser consideradas incipientes, a julgar pelo volume de informações disponibilizadas na literatura. A partir dos anos 90 surgem trabalhos na área e atualmente a frequência de avaliações tem sido maior. Dessa forma, é difícil falar em avanços metodológicos na microbiologia de silagens e fenos, sendo mais adequado uma abordagem dos avanços no emprego de metodologias propostas já há algum tempo. Segundo Jobim (1995), Bernardes (2003) e Coan (2005) principalmente as análises realizadas no Laboratório de Microbiologia do Departamento de Patologia Veterinária da FCAVUNESP-Câmpus de Jaboticabal-SP, tem seguido a rotina de: pesagem de determinada quantidade de silagem (matéria fresca) e posterior diluição em solução salina estéril $(8,5 \mathrm{~g}$ de $\mathrm{NaCl} / \mathrm{L}$ de água destilada). Jobim et al. (1997a) diluiram $100 \mathrm{~g}$ de amostra de silagem de grãos ou de espigas de milho em 900 mL de solução salina. Já em silagens de capins (Marandu e Tanzânia), Bernardes (2003) e Coan (2005) diluiram $25 \mathrm{~g}$ de silagem em $225 \mathrm{~mL}$ de solução salina. Após leve agitação, é retirado $10 \mathrm{~mL}$ do extrato para as diluições posteriores. A partir dos extratos diluídos $\left(10^{-1}\right.$ a $\left.10^{\mathrm{n}}\right)$ são realizadas as semeaduras $(0,1 \mathrm{~mL}$ por placa) nos meios específicos para cada microrganismo a ser determinado.

Outra forma para obtenção de amostras de silagem para análise microbiológica é recomenda por Lin et al. (1992). Uma amostra de $50 \mathrm{~g}$ é pesada em recipiente esterilizado contendo $450 \mathrm{~mL}$ de solução tampão fosfato de $\mathrm{K}$ dibásico $0,7 \mathrm{nM}(\mathrm{pH}$ 7,0 ) e homogeneizada por 40 segundos. Após essa etapa, são realizadas as diluições e plaqueamento nos meios de cultura seletivo.

Os tempos e temperaturas de incubação normalmente empregados são de 72 horas e 35 ${ }^{0} \mathrm{C}$. Para a contagem de Lactobacilos o meio de cultura utilizado é o Lactobacilli MRS Broth, com incubação em anaerobiose, em jarra com sistema Gás-Park. A diferenciação das bactérias ácido láticas em homofermentativas e heterofermen- tativas tem sido realizada segundo a metodologia descrita por McDonald et al. (1987).

Para a quantificação das enterobactérias em silagens emprega-se o meio de cultura Violet Red Bile Agar (Oxoid) com incubação em aerobiose, segundo metodologia descrita por Jonsson (1991). Já a presença de clostrideos em silagens tem sido monitorada segundo a metodologia descrita por Tosi et al. (1982), com cultura em meio Reinforced Clostridial Agar. Alguns autores (Jobim et al., 1997b, Bernardes, 2003) têm realizado a incubação a $30^{\circ} \mathrm{C}$, enquanto outros a $35^{\circ} \mathrm{C}$. A padronização na temperatura de incubação deve ser buscada visando melhorar as possibilidades de comparação de resultados entre laboratórios.

$\mathrm{Na}$ avaliação do desenvolvimento de leveduras e mofos (fungos filamentosos) as amostras são incubadas em meio Malt Extract Agar $\left(30{ }^{\circ} \mathrm{C} / 72\right.$ horas) acidificado com ácido lático para obtenção de $\mathrm{pH} 4,0$, segundo metodologia descrita por Tengerdy et al. (1991). É importante que haja uniformização dos tempos e temperaturas de incubação para que resultados possam ser comparados com certa coerência. Embora, a contagem e/ou identificação da população microbiana em forragens conservadas seja extremamente dinâmica, sendo influenciada pelas condições edafo-climáticas e de manejo da cultura no processo de ensilagem. Porém, a identificação da presença de microrganismos em conjunto com a determinação dos produtos da fermentação, são fatores fundamentais na avaliação da qualidade de forragens conservadas.

A presença de Listeria spp. tem sido detectada com freqüência em amostragens no campo e em silagens de capins, oferecendo risco potencial para a saúde dos animais. Especialmente no Brasil, temse observado avanços significativos em relação ao emprego de metodologias para o isolamento de Listeria spp. e Listeria monocytogenes. Esses procedimentos são descritos de forma detalhada por Silva (2002) e por Schocken-Iturrino et al. (2005). As análises para a identificação de Listeria compreendem vários testes: teste de catalase; teste de motilidade; teste de nitrato; reação em agar; tríplice açúcar ferro (TSI); teste de verificação de hemólise; teste de fermentação da dextrose, xilose, rhamnose, manitol, maltose e esculina.

A avaliação da ocorrência de microrganismos em fenos é menos freqüente e está mais relacionada à determinação da presença de fungos em

() 2007 Sociedade Brasileira de Zootecnia 
razão da possibilidade de produção de micotoxinas. No entanto, alguns trabalhos têm sido desenvolvidos com emprego de técnicas de rotina em laboratórios que utilizam testes de sanidade de semente.

\section{Medidas de perdas em silagens}

A maioria das medidas de perdas em silagens tem sido realizadas em silos de laboratório, com uso de tubos de PVC ou baldes plásticos providos de tampa adequada e válvula para eliminação de gases e areia para recuperação do efluente. Estas medidas podem ser de grande importância nas avaliações da qualidade de fermentação (padrão de fermentação) da forragem ensilada. No entanto, estas perdas podem ser, na maioria das vezes, subestimadas em relação a situação de campo devido ao maior controle no ambiente do silo de laboratório. Portanto, é importante realizar medidas de perdas também em situações de campo. Para isso, o uso de metodologia adequada é de fundamental importância.

As principais avaliações são de perdas totais de matéria seca e perdas por gases e efluentes. Estas medidas são obtidas pela pesagem dos silos laboratoriais vazios e cheios, antes e após a ensilagem, e dos respectivos teores de matéria seca.

\section{Perdas totais de matéria seca (\% MS)}

A determinação das perdas totais de matéria seca é calculada pela diferença entre o peso bruto de MS inicial e final dos silos, em relação à quantidade de forragem ensilada (MS). Deve ser descontado o peso do silo na ensilagem e na abertura, conforme equação descrita por Schmidt (2006).

$$
\begin{aligned}
& \text { PMS }=[\underline{(M S i-M S f})] \times \mathbf{1 0 0}, \\
& \text { MSi }
\end{aligned}
$$

onde:

PMS = Perda Total de MS;

MSi = Quantidade de MS inicial. Peso do silo após enchimento - peso do conjunto vazio, sem a forragem, antes do enchimento (tara seca) x teor de MS da forragem na ensilagem.

$\mathrm{MSf}=$ Quantidade de MS final. Peso do silo cheio antes da abertura - peso do conjunto vazio, sem a forragem, após a abertura dos silos (tara úmida) $\mathrm{x}$ teor de MS da forragem na abertura.

Alguns autores têm expressado esta informação na forma de Índice de Recuperação de Matéria Seca, empregando a seguinte equação:

\section{RMS $=($ MFab $x$ MSab $) /($ MFfe $\times$ MSfe $) * 100$}

Onde:

RMS = índice de recuperação de matéria seca;

$\mathrm{MFab}=$ massa de forragem na abertura;

$\mathrm{MSab}=$ teor de MS na abertura;

$\mathrm{MFfe}=$ massa de forragem no fechamento;

$\mathrm{Msfe}=$ teor de MS da forragem no fechamento.

Em situações de campo (silos de grande porte) a determinação da recuperação de MS pode ser feita com uso da técnica de sacos com amostras distribuídos no interior dos silos durante o processo de ensilagem (sacos traçadores). O uso de sacos distribuídos no interior dos silos como método de estudo da fermentação em silagens é discutido por McDonald et al. (1991). Abaixo é descrita a equação proposta por Schmidt (2006), onde:

RMSs $=100-[($ MFSe $\times$ MSSe $)-($ MFSr - MSSr $) \times 100]$ (MFSe x MSSe)

Em que:

RMSs =Recuperação de matéria seca no saco $(\%)$

MFSe $=$ Massa de forragem fresca no saco na ensilagem $(\mathrm{kg})$;

MSSe $=$ Teor de MS da forragem na ensilagem $(\%)$

$\mathrm{MFSr}=$ Massa de forragem fresca no saco recuperado $(\mathrm{kg})$;

MSSe $=$ Teor de MS da forragem no saco recuperado (\%).

O emprego dessa equação pressupõe que a diferença de peso do saco + massa de forragem na ensilagem e após a recuperação são perdas. É possível que a metodologia induza a erros de super estimação das perdas, ou seja, subestime a recuperação de matéria seca, uma vez que nem todo o material que desaparece do saco seria efetivamente 
computado como perdas no processo de ensilagem. Por outro lado, é possível haver aumento de peso da amostra pela entrada de material no saco durante o processo de ensilagem. Nesse contexto, Wardynski et al. (1993) avaliaram a recuperação de MS em silagem de grãos de milho com uso de sacos traçadores e registraram valores entre 101,10 e 96,93\% de recuperação de MS, enquanto que pela avaliação das quantidades de grãos ensilados e retirados dos silos a recuperação e MS variou entre 88,8 e $96,50 \%$.

Outra metodologia para determinar perdas em silos comerciais foi proposta por Ashbell \& Weinberg (1992) e está baseada na colocação de sacos distribuídos no silo durante o enchimento. No entanto, os sacos servem somente para definir um sitio de amostragem, na ensilagem e na recuperação dos sacos, uma vez que as perdas são estimadas com uso da cinza como indicador segundo a equação:

$\operatorname{MOp}(\%)=[1-(C F \times M O S) /(C S \times M O F F)] \times 100$,
2003), ou seja:

$$
P G=\frac{[(\text { PSf }- \text { PSa })] \times 100,}{\text { MFf } x \text { MSf }}
$$

$$
\begin{array}{ll}
\text { onde: } & \\
\mathrm{PG}= & \text { perda de gases durante o armaze- } \\
& \text { namento }(\% \text { da MS inicial }) ; \\
\mathrm{PSf}= & \text { peso do silo na ensilagem; } \\
\mathrm{PSa}= & \text { peso do silo na abertura; } \mathrm{MFf}=\text { massa } \\
& \text { de forragem na ensilagem; } \\
\mathrm{MSf}= & \text { teor de MS da forragem na ensilagem } .
\end{array}
$$

No entanto, essa equação pode subestimar as perdas por gases. Atualmente são propostas equações melhor ajustadas, visando maior acurácia da resposta, e que devem ser adotadas como padrão para estimativas das perdas por gases em silos de laboratório. Nesse contexto, Schmidt (2006) propôs nova equação para determinação das perdas por gases descontando-se a tara do silo experimental.

$$
\begin{array}{ll}
\text { onde: } & \begin{array}{l}
\text { porcentagem de matéria } \\
\text { orgânica perdida; } \\
\text { porcentagem de cinza na forragem } \\
\text { fresca; }
\end{array} \\
\mathrm{CS}= & \text { porcentagem de cinza na silagem; } \\
\mathrm{MOFF}= & \text { porcentagem de matéria orgânica na } \\
& \text { forragem fresca; } \\
\mathrm{MOS}= & \text { porcentagem de matéria orgânica na } \\
& \text { silagem. }
\end{array}
$$

Utilizando essa metodologia Jobim et al. (2006) estimaram perdas entre 13 e $16 \%$ em silagens de capim-Elefante com teores de matéria seca de 20,59 e $22,05 \%$, ensilado em silo trincheira. Os autores concluíram que as perdas estimadas foram equivalentes àquelas previstas para silagens com teores de matéria seca em torno de $20 \%$.

\section{Perdas gasosas (\% MS)}

A medida de perdas por gases no processo de ensilagem é obtida com base na pesagem dos silos de laboratório no fechamento e na abertura, em relação à massa de forragem armazenada. Alguns autores têm empregado a seguinte equação, sem descontar a tara dos silos experimentais (Mari,

\footnotetext{
onde:

$\mathrm{G}=\quad$ Perdas por gases em $\%$ da MS;

PCen $=$ Peso do silo cheio na ensilagem $(\mathrm{kg}) ;$

Pen $=$ Peso do conjunto (silo+tampa+areia +tela+pano) na ensilagem (kg);

MSen $=$ Teor de MS da forragem na ensilagem (\%);

PCab $=$ Peso do silo cheio na abertura $(\mathrm{kg})$;

$\mathrm{MSab}=$ Teor de MS da forragem na abertura $(\%)$.
}

\section{Perdas por efluente (kg/t MV)}

A produção de efluente tem sido calculada com uso estratégico de coletor no fundo dos silos de laboratório. $\mathrm{O}$ uso de areia seca tem mostrado eficiência, com cálculo da produção de efluente pela diferença de peso do conjunto silo+areia+ tela+pano na abertura (após retirar-se a forragem do silo) e antes da ensilagem, em relação a quantidade de forragem fresca ensilada. A desvantagem do método é a impossibilidade de análises da composição química em situações de interesse de caracterizar o efluente.

As seguintes equações podem ser empregadas

๑ 2007 Sociedade Brasileira de Zootecnia 
para quantificar as perdas por efluentes em silagens:

$$
\begin{array}{ll}
\text { Equação 1: PE }=\frac{\text { Pef x 1000 }}{\text { MVi }}, \\
\text { onde: } \\
\begin{array}{ll}
\mathrm{PE}= & \text { perdas por efluente; } \\
\mathrm{Pef}= & \text { peso de efluente (Peso do conjunto } \\
& \text { vazio após a abertura }- \text { peso do } \\
& \text { conjunto vazio antes do enchimento); } \\
\mathrm{MVi}= & \begin{array}{l}
\text { quantidade de massa verde de } \\
\text { forragem ensilada. }
\end{array}
\end{array}
\end{array}
$$

Equação 2 (proposta por Schmidt, 2006):

$$
E=\frac{(\text { Pab }- \text { Pen })}{(\text { MVfe })} \times 1000
$$

onde:

$\mathrm{E}=\quad$ Produção de efluente $(\mathrm{kg} / \mathrm{t}$ de massa verde);

$\mathrm{Pab}=$ Peso do conjunto (silo+areia+ pano+tela) na abertura (kg);

Pen $=$ Peso do conjunto (silo+areia+pano +tela) na ensilagem $(\mathrm{kg})$;

MVfe $=$ Massa verde de forragem ensilada $(\mathrm{kg})$.

\section{Caracterização do efluente em silagens}

A caracterização do efluente de silagens tem sido pouco freqüente no Brasil. No entanto, dado ao crescente uso de silagens de capins, as quais invariavelmente produzem quantidades significativas de efluentes (Aguiar et al., 2000; Bernardes, 2003; Coan, 2005), esta avaliação deve se tornar mais freqüente. $\mathrm{O}$ volume de efluente produzido em um silo é influenciado por vários fatores, destacando-se o teor de MS, tamanho de partícula, processamento, tipo de silo e compactação.

Para a avaliação da composição do efluente é necessário adaptar o silo para a coleta do exudado. Isso é facilmente possível em silos de laboratório. Várias são as substâncias indesejáveis presentes no efluente (Reis \& Coan, 2001), além de compostos orgânicos como açúcares, ácidos, proteína e minerais (Nussio et al., 2002). As perdas desses compostos no efluente afetam diretamente a concentração de nutrientes na silagem e por conseqüência, a qualidade da mesma. Já outras substâncias, como aquelas provenientes da degradação de aminoácidos (cadaverina, putrescina, histamina e demais aminas biogênicas), amônia também afetam negativamente a qualidade da silagem, pois são decorrentes de fermentações secundárias. Além da redução no valor nutricional da silagem, Nussio et al. (2002), destacam os riscos de contaminação ambiental, particularmente se o efluente escoar para cursos d'agua ou lençóis freáticos.

A caracterização do efluente em silagens pode ser realizada com análises do teor de MS, N-total e principalmente pela demanda bioquímica de oxigênio (DBO) e pela demanda química de oxigênio (DQO). A DBO é definida como a quantidade de oxigênio $(\mathrm{mg} / \mathrm{L})$ necessária para estabilizar a matéria orgânica, por microrganismos aeróbios, num período de cinco dias a $20^{\circ} \mathrm{C}$. Assim, quanto maior for o teor de matéria orgânica biodegradável, maior será a demanda de oxigênio pelas bactérias, elevando a DBO. Já a DQO é definida como a quantidade de oxigênio $(\mathrm{mg} / \mathrm{L})$, necessária para estabilizar a matéria orgânica, com uso de um forte oxidante, como o dicromato de potássio. Portanto, entende-se por DBO a quantidade de oxigênio molecular necessária à estabilização da matéria orgânica carbonada decomposta aerobicamente por via biológica e $\mathrm{DQO}$ a quantidade de oxigênio molecular necessária a estabilização da matéria orgânica por via química.

A determinação da DBO e da DQO em efluente de silagens tem sido realizada por pesquisadores brasileiros (Coan, 2005, Loures et al., 2005) com base no protocolo analítico da APHA (1995) e também segundo Silva (1977). Loures et al. (2003) registraram valores de DBO de 14.596,69 mg/L e de DQO de 31.138,20 em efluente de silagem de capim-Elefante. A relação DBO/DQO foi de 2,38, revelando que esse efluente é facilmente biodegradável. No entanto, conforme destacam os autores esse efluente é considerado com alta capacidade de poluição frente ao que determina a legislação brasileira (valores entre $60-90 \mathrm{mg} / \mathrm{L}$ para esgotos e dejetos lançados em cursos de água e rios). Em outro artigo, Loures et al. (2005) ao avaliarem o efluente produzido por silagem de capimTanzânia concluíram que a silagem apresentou efluente com elevado potencial poluidor para o meio ambiente em função dos valores de DBO $(11.289 \mathrm{mg} / \mathrm{L})$, DQO $(36.279 \mathrm{mg} / \mathrm{L})$ e relação DQO/DBO $(3,35)$ observadas. 
Segundo Deberdt (2007) uma das limitações da DQO é o fato de que o teste não diferencia MO biodegradável e MO não biodegradável. A vantagem é o tempo reduzido para obtenção do resultado do teste, enquanto que a DBO requer no mínimo cinco dias para gerar resultados.

\section{Determinação da estabilidade em aerobiose}

A estabilidade aeróbia da silagem pode ser conceituada como a resistência da massa de forragem a deterioração após a abertura do silo, ou seja, a velocidade com que a massa deteriora após exposta ao ar. Oude Elferink et al. (2000) definiram estabilidade aeróbia como a resistência ao aumento da temperatura da silagem no painel do silo durante a oferta aos animais no cocho. Outros autores definiram a elevação em $2{ }^{\circ} \mathrm{C}$ na temperatura da silagem exposta ao ar, em relação ao ambiente, como medida de rompimento da estabilidade aeróbia (O’Kiely et al., 2001). Nesse caso a ênfase está na metodologia de estimação da estabilidade da silagem, o que não se deve confundir com o conceito de estabilidade em aerobiose.

A estabilidade da silagem é determinada pela oxidação de substrato que ocorre após a abertura do silo. Portanto, a concentração de oxigênio e a profundidade que $\mathrm{o}$ ar penetra no silo são fatores preponderantes. Isso evidencia que a $\mathrm{ME}$ da silagem $\left(\mathrm{kg}\right.$ de silagem $\left./ \mathrm{m}^{3}\right)$ determina a porosidade da silagem e, por conseqüência, a concentração de oxigênio no painel do silo. A atividade dos microrganismos que decompõem a silagem será mais intensa, quanto melhor for a qualidade da silagem, em função dos maiores teores de carboidratos solúveis e de ácido lático residuais. Os principais substratos utilizados são os ácidos, o etanol e os açúcares solúveis, resultando em aumento do pH e redução na digestibilidade e no conteúdo de energia.

As pesquisas sobre deterioração de silagens durante a utilização evidenciam que a temperatura, a concentração de carboidratos solúveis, a população de fungos e leveduras e a concentração de ácidos orgânicos em interação com o pH são os parâmetros que mais afetam a estabilidade das silagens durante a fase de utilização. $\mathrm{O}$ aumento do pH após a exposição da silagem ao ar, queda no teor de carboidratos solúveis e baixa concentração de ácido lático são importantes indicadores da deterioração da massa. Mas em condições de campo, a deterioração da silagem pode ser facilmente identificada pela elevação da temperatura no painel do silo.

Durante a utilização da silagem é inevitável a exposição do painel do silo ao $\mathrm{O}_{2}$, com conseqüente crescimento de microrganismos aeróbios e perda de componentes nutritivos da silagem. A preocupação com estas perdas na fase de utilização da silagem levou pesquisadores de diferentes partes do mundo a concentrarem pesquisas com esse enfoque.

Embora já na década de 70 as pesquisas em silagens buscavam reduzir a atividade de leveduras e fungos em silagens com uso de aditivos ácidos (Ohyama et al., 1975), somente nos últimos anos tem havido avanços técnicos no sentido de reduzir a deterioração de silagens durante o período de utilização. Grandes avanços tecnológicos foram obtidos, principalmente em relação ao uso de inoculantes bacterianos heterofermentativos, com bactérias específicas (Lactobacillus buchneri $\mathrm{e}$ Lactobacillus plantarum) e também com uso de aditivos químicos como benzoato de sódio, uréia, amônia.

A sofisticação metodológica vem permitindo observar pequenas alterações de temperatura, com boa precisão. A substituição de leituras em termômetros de bulbo por pares termo-elétricos e, mais recentemente, por sistemas eletrônicos/digitais de aquisição de dados (data loggers) com grande freqüência de mensurações, melhorou sensivelmente a qualidade dos dados obtidos em relação à estabilidade aeróbia. Em estudo sobre freqüência de observação de temperaturas, Figueiró et al. (2005) usaram método eletrônico de avaliação de temperatura (dataloggers), programados para aquisição dessa variável a cada 15 minutos, em silagens de cana-de-açúcar expostas ao ar. Os autores verificaram que leituras de temperatura a cada cinco horas são necessárias para se detectar variações mínimas de $2{ }^{\circ} \mathrm{C}$ na silagem em aerobiose.

Alguns pesquisadores têm estimado a estabilidade aeróbia como sendo o tempo para elevação da temperatura da silagem em $1{ }^{\circ} \mathrm{C}$ acima da temperatura ambiente, conforme definido por Driehuis et al. (2001). Porém, mesmo em ambientes com temperatura controlada, a elevação

๑ 2007 Sociedade Brasileira de Zootecnia 
de temperatura em $1{ }^{\circ} \mathrm{C}$ pode não fornecer resultados coerentes com o que acontece com a silagem em situação de fornecimento aos animais.

Acredita-se que as medidas de estabilidade aeróbia de silagens deveriam ser realizadas em condições o mais próximo possível da situação de campo. É sabido que a temperatura afeta de forma significativa o crescimento e atividade dos microrganismos que atuam nas silagens. Assim, a elevação da temperatura diurna e queda noturna podem resultar em mudanças significativas na atividade dos microrganismos. As avaliações em ambientes com temperatura controlada são fundamentais para comparar tratamentos, e até o presente, a única solução metodológica para pesquisa. Mas pode ser de baixa acurácia para estimar, de fato, a velocidade de deterioração da silagem em situação de campo.

Outro fator relevante é que quando misturada aos demais alimentos da ração no cocho, a silagem tem sua estabilidade alterada em relação à silagem exclusiva. Considerando-se que, nessas condições, haverá alteração nas características físicas (ex.: porosidade, massa específica) e químicas da silagem (ex.: pH, teor de substrato), parece claro que a dinâmica de atividade dos microrganismos que deterioram a silagem é alterada. Nesse contexto, estudos foram realizados para avaliar a velocidade de deterioração da silagem no cocho. Como exemplo veja os trabalhos de O'Kiely et al. (2001) e de Schmidt (2006). Os resultados têm mostrado haver redução na velocidade de deterioração da silagem no cocho. Nas condições brasileiras, Schmidt (2006) concluiu que a estabilidade da silagem de cana-de-açúcar foi elevada pela adição de ingredientes concentrados às silagens.

As variáveis temperatura e $\mathrm{pH}$, pela facilidade de determinação e baixo custo, são as mais usadas na atualidade na avaliação da estabilidade aeróbia de silagens. Em anos recentes essas variáveis vêm sendo exploradas de diferentes formas, conforme pode ser visualizado nas publicações de O'Kiely et al. (2001), Cherney \& Cherney (2003) e Schmidt (2006). Os valores de temperatura observados têm sido apresentados como:

a) Temperatura máxima registrada após a abertura dos silos;

b) Tempo para atingir temperatura máxima;

c) Diferença máxima entre a temperatura da silagem e do ambiente; d) Somatório das diferenças de temperatura das silagens e do ambiente;

e) Tempo para que a temperatura das silagem apresente tendência de elevação;

f) Tempo para que a silagem eleve a temperatura em $2{ }^{\circ} \mathrm{C}$.

As mesmas formas de apresentação dos dados podem ser usadas em relação aos valores de $\mathrm{pH}$, como por exemplo: pH máximo; tempo para atingir pH máximo, etc.

No entanto, cabe o questionamento em relação a estabilidade da silagem na ração total: A avaliação da estabilidade aeróbia de silagens somente pela medida de variações de temperatura é suficiente? No cocho pode haver diluição da temperatura gerada pela atividade microbiológica. Acredita-se que medidas de $\mathrm{pH}$ associado ao monitoramento de temperatura podem resultar em avaliações mais efetivas de deterioração da silagem. A estabilidade aeróbia de silagens pode ser mais bem avaliada com estudo do crescimento da população microbiana, uma vez que o processo de deterioração aeróbia é essencialmente microbiano, porém isso implica em gastos mais elevados.

Nesta linha de pesquisa, Bernardes et al. (2007) conduziram estudo com o intuito de avaliar a estabilidade aeróbia das silagens e da ração total contendo silagens de capim-Marandu, e utilizaram a metodologia de avaliação em câmara climática com temperatura constante de $25 \pm 1^{\circ} \mathrm{C}$, determinaram as recuperações de MS e as alterações nos valores de $\mathrm{pH}$ da silagem.

Outra variável importante nas estimativas da estabilidade aeróbia de silagens é a medida do $\mathrm{CO}_{2}$ liberado durante a exposição ao ar. Essa metodologia, proposta por Ashbell et al. (1990), está estabelecida com base na titulação de uma solução de $\mathrm{KOH}$ como coletora do $\mathrm{CO}_{2}$ liberado pela atividade dos microrganismos na silagem exposta ao ar. O método de medida da quantidade de $\mathrm{CO}_{2}$ liberado pode ser um real indicador da deterioração da silagem, porém é de custo mais elevado em relação àqueles baseados nas medidas de temperatura, associados ou não as medidas de $\mathrm{pH}$.

Outro avanço na metodologia de avaliação da deterioração aeróbia em silagens é por meio de representação termográfica das alterações de temperatura no painel do silo durante o período 
de utilização, conforme apresentado por Bernardes (2006). A metodologia prevê a identificação dos principais regiões do painel do silo onde está havendo deterioração por meio de medidas de temperatura em vários pontos do painel. Os dados obtidos são lançados em planilha do programa Excel e posteriormente são produzidas imagens com escala calorimétricas utilizando o software Surfer.

Como o calor gerado significa atividade microbiológica deteriorando a silagem a imagem possibilita a análise das principais regiões do silo onde ocorrem maiores atividades dos microrganismos, podendo proporcionar importantes informações ao pesquisador.

Pode-se afirmar que a metodologia para estudo da estabilidade aeróbia de silagens está bem definida e possibilita avaliação com certa precisão da velocidade de deterioração de silagens. Porém, entende-se que os estudos sobre a estabilidade das silagens não devem ser limitados às perdas nessa fase. O olhar deve se voltar para os efeitos de silagens deterioradas sobre a ingestão, desempenho de animais e qualidade do produto.

\section{Determinações de consumo e digestibilidade}

O consumo ad libitum é o fator de maior influência sobre a qualidade da forragem, o qual afeta diretamente o desempenho animal. O consumo é afetado pelos fatores inerentes ao animal e a forragem, com ênfase na aceitabilidade e na seleção (Van Soest, 1994).

De acordo com Charmley (2001), de maneira geral o consumo das silagens é menor do que o da forragem original que não sofreu processo de fermentação. Segundo Van Soest (1994), existem três hipóteses associadas ao baixo consumo de silagens:

1- Presença de substancias tóxicas, como aminas produzidas durante o processo de fermentação,

2- Alto conteúdo de ácidos nas silagens extensivamente fermentadas, causando redução na aceitabilidade, e

3- Diminuição na concentração de carboidratos solúveis e, conseqüentemente, na disponibilidade de energia para o crescimento de microrganismos do rúmen. Desta forma é de suma importância a determinação destes compostos a fim de se estabelecer as relações entre o consumo de forragem e a composição química.

De maneira geral, o consumo voluntário de forragem conservado é avaliado nos experimentos de determinação da digestibilidade in vivo, mediante pesagem do alimento fornecido, em geral 15 a $20 \%$ do consumido e das sobras. A composição química das sobras pode diferir acentuadamente daquela da forragem fornecida. Uma estratégia adequada é a redução do tamanho das partículas com vistas a minimizar os efeitos do processo de seleção. Em experimentos nos quais os animais são alimentados em grupo, tem-se a necessidade do uso de indicadores para a obtenção do consumo individual.

A ingestão potencial de MS da silagem é determinada pelo tipo de forragem, composição química e digestibilidade no momento da colheita, mas a extensão na qual este potencial é alcançado depende, na prática, das modificações das frações carboidratos e de compostos nitrogenados durante a fermentação, bem como da deterioração durante a fase de exposição ao oxigênio (Nussio et al., 2003). Esses autores, em sua revisão de literatura, avaliaram o trabalho de Huhtanen et al. (2002), no qual foram considerados os fatores relacionados às características biológicas e químicas da silagem com a ingestão de MS utilizando-se, para isto, de dados históricos de estudos prévios para o estabelecimento de equações de regressão simples ou múltiplas. Segundo os autores, o desempenho dessas equações de predição, por meio de parâmetros de fermentação, tem se mostrado insatisfatório, apresentando baixo $\mathrm{R}^{2}$ e resultando em erros de predição como conseqüência de características relacionadas aos animais (raça, peso, sexo, idade, produto), sistema de alimentação e suplementação.

Adotando a equação proposta por Huhtanen et al. (2002), ou seja:

$$
\begin{gathered}
\text { Índice de consumo }=100+0,151 *(\mathrm{D}-690) \\
-0,000531 *\left(\mathrm{TA}^{2}-6400\right)-4,7650 * \\
{[\operatorname{Ln}(\mathrm{N}-\mathrm{NH} 3)-\operatorname{Ln}(\mathbf{5 0})]}
\end{gathered}
$$

assumindo os melhores perfis das análises de silagens de gramíneas, valores de D = $690(\mathrm{~g} / \mathrm{kg}$

๑๐ 2007 Sociedade Brasileira de Zootecnia 
MS); ácidos totais (AT) = $80(\mathrm{~g} / \mathrm{kg} \mathrm{MS})$ e Namoniacal $(\mathrm{N}-\mathrm{NH} 3)=50(\mathrm{~g} / \mathrm{kg} \mathrm{N}$ total $)$.

Em um trabalho de revisão, Nussio et al. (2003) substituíram os termos dessa equação por valores encontrados regularmente nas silagens de gramíneas tropicais: $\mathrm{D}=530 ; \mathrm{TA}=180$ e $\mathrm{N}-\mathrm{NH}_{3}$ $=100$, obtendo o índice relativo de consumo de $58,74 \%$ em relação ao padrão. Segundo os autores, o menor potencial de ingestão das silagens de gramíneas tropicais, previsto pelo modelo, resultou principalmente do baixo valor D e da elevada concentração de ácidos (TA). Os autores concluíram que para silagens de gramíneas tropicais, os experimentos, nas últimas três décadas, mostram baixa ingestão, utilização ineficiente da energia e suprimento baixo e desbalanceado de aminoácidos. Essas limitações significam que a silagem de gramíneas não supre os requerimentos dos animais de alta produção sem suplementação mas, em algumas situações, representam uma importante fonte de volumosos suplementares.

A digestibilidade pode ser adequadamente estimada por meio de dispositivos que simulam as condições de fermentação ruminal utilizando métodos in vitro, in situ e a produção de gases (Van Soest, 1994). Em 1966, Hungate (2002) indicou que a digestibilidade in vivo poderia ser predita de procedimentos in vitro que recriaram as condições do rúmen e do abomaso. Por este motivo foi desenvolvido o ensaio de digestibilidade gravimétrico de dois estágios por Clark (1958) citado por Mott \& Moore (1970) e logo modificado e conhecido como procedimento Tilley \& Terry (1963).

Os processos in vitro, geralmente compreendem uma fase inicial de fermentação utilizando líquido de rúmen, ou mesmo enzimas seguido de outra fase na qual se faz a digestão utilizando pepsina ácida (Tilley \& Terry, 1963) ou mesmo a solução detergente neutro (Van Soest, 1994). A vantagem da extração com detergente neutro é a diminuição no tempo de análise e a determinação da digestibilidade in vitro verdadeira, uma vez que se elimina do resíduo toda a fração metabólica. A digestibilidade verdadeira in vitro da matéria seca (DVIVMS) e da matéria orgânica (DVIVMO) tem sido determinadas com base no método ANKOM* Fiber Analyser (ANKON Technology Corporation), descrito por Holden (1999).
A técnica in situ para a caracterização dos alimentos no rúmen foi citada pela primeira vez em 1930 e tem sido amplamente adotada em todo mundo para avaliar a taxa e a extensão de degradação do alimento no rúmen em função do tempo de incubação (Huntington \& Givens, 1995). Apesar de ter sido inicialmente usada para avaliação da degradabilidade da proteína, a técnica in situ também tem sido recomendada para avaliação do desaparecimento da matéria seca e dos constituintes fibrosos das forragens (Mehrez \& ØRSKOV, 1977; ØRSKOV \& McDonald, 1979, ØRSKOV, 2000). Esta técnica possui como vantagens a rápida e fácil execução, a necessidade de amostras pequenas de alimento e o fato de permitir o contato íntimo entre o alimento testado e o ambiente ruminal. Sendo assim, considerada a técnica ideal para simular o ambiente ruminal dentro de um determinado regime alimentar específico, apesar do alimento não sofrer os efeitos da mastigação, ruminação e do escape ruminal.

A metodologia de produção de gás tem a vantagem de permitir a avaliação da taxa e da extensão da fermentação, utilizando aparatos simples e de baixo custo (Williams, 2000). É oportuno salientar que na avaliação de forragens submetidas a tratamentos químicos, os quais promovem a solubilização de compostos indigestíveis, como os produtos solúveis oriundos da reação de Maillard a utilização de métodos gravimétricos não é recomendada para a avaliação dos valores de digestibilidade. Nesta condição, admitese que todos os compostos solubilizados são considerados como digeridos, o que não é verdadeiro, levando a superestimativa do valor nutritivo do alimento. A utilização da técnica de produção de gases permite a avaliação mais precisa do valor nutritivo de forragens tratadas com produtos químicos, ou mesmo aquelas submetidas a condições adversas de fermentação, de secagem e de conservação.

\section{Considerações finais}

A avaliação das metodologias atualmente empregadas nos estudos de qualidade de forragens conservadas, especialmente silagens, evidencia que há constante busca no desenvolvimento de metodologias e aperfeiçoamento das já existentes ou que foram desenvolvidas para estudos de outros 
tipos de alimentos. Especialmente nas pesquisas realizadas por pesquisadores brasileiros fica evidente o crescimento no uso de novas metodologias na avaliação de silagens, visando avaliar variáveis que eram consideradas de pouca relevância. Os recursos metodológicos disponíveis atualmente permitem não somente quantificar, mas também qualificar perdas ocorridas no processo de conservação, exposição aeróbia e oferta dos volumosos aos animais. Esse fato sugere que a adoção de estratégias de manejo dessas forragens deverá, preferencialmente, ser acompanhada de avaliação de perdas integradas no processo.

\section{Literatura citada}

AGUIAR, R.N.S.; CRESTANA, R.F.; BALSALOBRE, M.A.A et al. Avaliação das perdas de matéria seca em silagem de capim-Tanzânia. In: REUNIÃO ANUAL DA SOCIEDADE BRASILEIRA DE ZOOTECNIA, 37, 2000. Viçosa-MG Anais... Viçosa., 2000. (DC ROM).

APHA - American Public Health Association. Standart Methods for the Examination of Water and Wastewater, 19 Ed. Washington, D.C.: APHA, 1995, 1268p.

ASHBELL, G.; WEINBERG, Z.G.; ARIELI, Y.H. et al. A simple system to study the aerobic determination of silages. Technical Notes, Canadian Agricultural Engeniering, v.33, p.391393, 1990.

ASHBELL, G.; WEINBERG, Z.G. Top silage losses in horizontal silos. Canadian Agricultural Engeniering, v. 34, n.2, p.171175, 1992.

BERNARDES, T.F. Controle da deterioração aeróbia de silagens. Tese (Doutorado em Zootecnia). Faculdade de Ciências Agrárias e Veterinárias, Universidade Estadual Paulista, Jaboticabal. 103p., 2006.

BERNARDES, T.F. Características fermentativas, microbiológicas e químicas do capim-Marandu (Brachiaria brizantha (Hochst. Ex. A. Rich.) Stapf cv. Marandu) ensilado com polpa cítrica peletizada. Dissertação (Mestrado em Zootecnia) - Faculdade de Ciências Agrárias e Veterinárias, Universidade Estadual Paulista, Jaboticabal. 108p., 2003.

BERNARDES, T.F.; REIS, R.A.; SIQUEIRA, G.R. et al. Estabilidade aeróbia da ração total e das silagens de capimMarandu submetidas a inclusão de aditivos bacterianos e químico. Revista Brasileira de Zootecnia, v.36, n.4, prelo, 2007.

BOLSEN, K.K.; LIN, C.; BRENT, B.E. et al. Effect of silage additives on the microbial succession and fermentation process of alfalfa and corn silages. Journal of Dairy Science, v.75. p.3066-3083, 1992.

BUXTON, D.R.; MUCK, R.E.; HARRISON, J.H. Silage Science and Technology. American Society of Agronomy, Inc. Madison, Wisconsin, USA. 2003. 927p.

CAMPOS, F.P; NUSSIO, C.M.B; NUSSIO, L.G. Métodos de Análise de Alimentos. FEALQ, Piracicaba, 2004, 135p.

CASTRO, F.G.; NUSSIO, L.G.; SIMAS, J.M.C. et al. Parâmetros físicos-químicos da silagem de tifton-85 (Cynodon spp.) sob efeito do pré-murchamento e de inoculante bacteriano-enzimático. In: REUNIÃO ANUAL DA SOCIEDADE BRASILEIRA DE ZOOTECNIA, 38., Piracicaba, 2001. Anais... 2001. p.270-272.

CHARMLEY, E. Towards improve silage quality: Areview. Can J. Anim. Sci., v 81, p. 57-168. 2001.

CHERNEY, J.H.; CHERNEY, D.J.R. Assessing Silage Quality.
In: Buxton et al. Silage Science and Technology. Madison, Wisconsin, USA. 2003. p.141-198.

COAN, R.M. Avaliação da polpa cítrica peletizada como aditivo no processo de ensilagem dos capins Tanzânia e Marandu. Tese (doutorado em Zootecnia). Faculdade de Ciências Agrárias e Veterinárias, Universidade Estadual Paulista, Jaboticabal. 205p., 2005.

COLLAO SAENZ, E.A. Modelagem da redução do tamanho de partículas na alimentação de ruminantes. Ciência e Agrotecnologia, v.29, n.4, p.886-893, 2005.

DEBERT, A.J. <http://educar.sc.usp.br/biologia/prociencias/ qagua.htm> Acesso em: 29 mar. 2007.

DITCHFIELD, C. Estudos dos métodos para a medida da atividade de água. Dissertação (Mestrado em Engenharia) Escola Politécnica, Universidade de São Paulo. 195p., 2000.

DRIEHUIS, F.; OUDE ELFERINK, S.J.W.H.; Van WIKSELAAR, P.G. Fermentation characteristics and aerobic stability of grass silage inoculated with Lactobacillus buchneri, with or without homofermentative latic acid bacteria. Grass and Forrage Science, v.56, p.330-343, 2001.

FIGUEIRÓ, R.N.; SOUSA, D.P.; NUSSIO, L.G. et al. Freqüência crítica para avaliação da temperatura em ensaio de estabilidade aeróbia em forragens e rações. In: REUNIÃO ANUAL DA SOCIEDADE BRASILEIRA DE ZOOTECNIA, 42, 2005 , Goiânia. Anais... Goiânia: SBZ, 2005. CD ROM.

GARCIA, D.M. Análise de atividade de água em alimentos armazenados no interior de granjas avícolas. Acta Scientiae Veterinariae, v.32, n.3, p.251-252, 2004.

GREENHILL, W.L. Plant juice in relation to silage fermentation. Journal of the British Grassland Society, v.19, p.336-339, 1964.

HEINRICHS, A.J.; BUCKMASTER, D.R.; LAMMERS, B.P. Processing, mixing, and particle size reduction of forages for dairy cattle. Journal of Animal Science, n.77, p.180186, 1999.

HEINRICHS, A.J Evaluating particle size of forages and TMRs using the Penn State Particle Size Separator. Dairy \& Animal Science, n.20, p.01-09, 1996. Disponível em: <www.das.psu. edu/dairynutrition/documents/oldparticle9620.pdf>. Acesso em: 25 mar. 2007.

HOLDEN, L.A. Comparison of methods of in vitro dry matter digestibility for ten feeds, Journal of Dairy Science, v.82, n.8, p. 1791-1794, 1999.

HOLMES, B.J.; MUCK, R.E. Factors affecting bunker silo densities. 1999. 7p. Disponivel em: <http://www.uwex.edu/ ces/crops/uwforage/BunkDens3.PDF> Acesso em: 15 abr. 2007.

HUHTANEN, P. New developments in the prediction of intake of silage based diets. In: THE INTERNATIONAL SILAGE CONFERENCE, $13^{\text {th }}, 2002$, Auchincruive. Proceedings... Auchincruive, 2002, p.236-251.

HUNGATE, R.E. The rumen and its microbes. New York: Academic Press, 1966. 533 p.

HUNTINGTON, J.A.; GIVENS, D.I. The in situ technique for studying the rumen degradation of feeds: A review of the procedure. Nutr. Abstr. Rev. Ser. B, Abeerden, v.65, n.2, p.63-93, 1995.

IGARASI, M.S. Controle de perdas na ensilagem de capim Tanzânia (Panicum maximum Jacq. Cv. Tanzânia) sob os efeitos do teor de matéria seca, do tamanho de partícula, da estação do ano e da presença do inoculante bacteriano. 151p. Dissertação (Mestrado em Agronomia) - Escola Superior Agrícola "Luiz de Queiroz", Universidade de São Paulo, Piracicaba. 151p., 2002.

JOBIM, C.C. Avaliação das características microbiológicas, químicas e digestibilidade das silagens de grãos úmidos e de espigas de milho. Tese (Doutorado em Zootecnia) Faculdade de Ciências Agrárias e Veterinárias, Universidade Estadual Paulista, Jaboticabal. 98p., 1995.

JOBIM, C.C.; REIS, R.A.; RODRIGUES, L.R.A. Avaliação da 
silagem de grãos úmidos de milho (Zea mays L.). Pesquisa Agropecuária Brasileira, v.32, n.3, p.311-31, 1997a. JOBIM, C.C.; REIS, R.A.; RODRIGUES, L.R.A. et al. Presença de microrganismos na silagem de grãos úmidos de milho ensilado com diferentes proporções de sabugo. Pesquisa Agropecuária Brasileira, v.32, n.2, p.201-204. 1997b

JOBIM, C.C.; SARTI, L.L.; SANTOS, G.T. et al. Desempenho animal e viabilidade econômica do uso da silagem de capimelefante em substituição a silagem de milho para vacas em lactação. Acta Scientiarum Animal Science, p.127-135, 2006.

JONSSON, A. Growt of Clostridium tyrobutiricum during fermentation and aerobic deterioration of grass silage. Journal Science Food Agriculture, v.54, p.557-568, 1991.

KRAUS, T.J.; KOEGER, R.G.; STRAUB, R.J. et al. Leachate conductivity as an index for quantifying level of forage conditioning. In: ASAE ANNUAL INTERNATIONAL MEETING, 1997, Minneapolis: ASAE, 1997. 12p.

KUNG JUNIOR, L.; GRIEVE, D.B.; THOMAS, J.W. et al. Added ammonia or microbial inocula for fermentation and nitrogenous compounds of alfafa ensiled at various percents of dry matter. Journal of Dairy Science, v.67, p.299-306, 1984.

LAMMERS, B.P.; BUCKMASTER, D.R.; HEINRINCHS, A.J. A simple method for the analysis of particle size of forage and total mixed rations. Journal of Dairy Science, v.79, p.922-928, 1996.

LIN, C.; BOLSEN, K.K.; BRENT, B.E. et al. Epiphytic micloflora on alfafa andwhole-plant corn. Journal of Dairy Science, v.75, p.2484-2493, 1992.

LINDGREN, S. Can HACCP Principles be applied for silage safety? In: INTERNATIONAL SILAGE CONFERENCE, 7. Uppsala, 1999. Proceedings... Uppsala: Swedish University of Agricultural Science, 1999. p.51-66.

LOURES, D.R.S.; GARCIA, R.; PEREIRA, et al. Características do efluente e composição químico-bromatológica da silagem de capim-elefante sob diferentes níveis de compactação. Revista Brasileira de Zootecnia, v.32, n.6, p.1851-1858, 2003 (supl.2).

LOURES, D.R.S.; NUSSIO, L.G.; PAZIANI, S.F. et al. Composição bromatológica e produção de efluente de silagem de capim-Tanzânia sob efeito de emurchecimento, do tamanho de partícula e do uso de aditivos biológicos. Revista Brasileira de Zootecnia, v.34, n.3, p.726-735, 2005.

MARI, L.J. Intervalo entre cortes em capim-marandu (Brachiaria brizantha (Hochst ex. A.Rich.) Stapf cv. Marandu): produção valor nutritivo e perdas associadas à fermentação da silagem. Dissertação (Mestrado em Agronomia). - Escola Superior Agrícola "Luiz de Queiroz", Universidade de São Paulo, Piracicaba. 159p., 2003.

MARI, L.J.; NUSSIO, L.G. O método Penn State Particle Size Separator para a predição do tamanho de partículas de silagens. 2002. Disponível em: <http://www.beefpoint. com.br/bn/radarestecnicos>. Acesso em: 12 abr. 2007.

McDONALD, P.; HENDERSON, A.R.; HERON, S.J.E. The Biochemistry of Silage. 2.ed. Marlow. Chalcombe Publications, 1991. 226p.

McDONALD, P.; McFEETERS, R.F.; DAESCHEL, M.A. et al. A differential medium for the enumeration of homofermentative lactic acid bacteria. Applied Enviromental Microbiology, v.53, n.6, p.1382-1384, 1987.

MEHREZ, A.Z.; ØRSKOV, E.R.; McDONALD, I. Rates of rumen fermentation in relation to ammonia concentration. British Journal of Nutrition, v.38, p. 433-443, 1977.

MOTT, G.O.; MOORE, J.E. Forage evaluation techniques in perspective. In: BARNES, R.F.; CLANTON, D.C.; GORDON, C.H.; KLOPFENSTEIN, T.J.; WALDO, D.R. (Ed). Forage quality evaluation and utilization. Nebraska: Nebraska Center for Continuing Education, 1970, p L1-L10.

MUCK, R.E.; HOLMES, B.J. Factors affecting bunker silo densities. Applied Engeniering in Agriculture, v.16, p.613$619,2000$.
MUCK, R.E.; HOLMES, B.J. Factors affecting bag silo densities and losses. In: INTERNATIONAL SILAGE CONFERENCE, 14., 2005, Belfast. Proceedings... Belfast: Wageningen Academic Publishers, 2005, p.245.

NUSSIO, L.G.; SCHMIDT, P. Tecnologia de produção e valor alimentício de silagens de cana-de-açúcar. In: SIMPÓSIO SOBRE PRODUÇÃO E UTILIZAÇÃO DE FORRAGENS CONSERVADAS, 2., 2004. Maringá. Anais... Maringá: UEM, 2004. p.1-33.

NUSSIO, L.G.; PAZIANI, S.F.; NUSSIO, C.M.B. Ensilagem de capins tropicais. In: REUNIÃO ANUAL DA SOCIEDADE BRASILEIRA DE ZOOTECNIA, 39, 2002. Recife. Anais... Recife, 2002. p.60-99.

NUSSIO, L.G.; RIBEIRO, J.L.; PAZIANI, S.F. et al. Fatores que interferem no consumo de forragens conservadas. In: Volumosos na Produção de Ruminantes: Valor Alimentício de Forragens. Reis, R.A.; Bernardes, T.F.; Siqueira, G.R.; Moreira, A.L. (Ed.). 2003. Jaboticabal. Anais..., FUNEP. p. 27-50. 2003.

OHYAMA, Y.; MASAKI, S.; HARA, S. Factors influencing aerobic deterioration of silages and changes in chemical composition after opening silos. Journal of the Science of Food and Agriculture, v.26, p.1137-1147, 1975.

O’KIELY, P.O.; CLANCY, M.; DOYLE, E.M. Aerobic stability of grass silage mixed with a range of concentrate feedstuffs at feed-out. In: INTERNATIONAL GRASSLAND CONGRESS, 19, 2001. São Pedro-SP. Proceedings... Piracicaba-FEALQ, 2001. p.794-795.

ØRSKOV, E.R.; McDONALD, I. The estimation of protein degradability in the rumen from incubations measurements weighted according to the rate of passage. Journal of Agricultural Science, v.92, n.2, p. 499-503, 1979.

ØRSKOV, E.R. The in situ technique for the estimation of forage degradability in ruminants. 2000. In: Forage evaluation in ruminant nutrition. Givens, D.I., Owen, E., Axford, R.F.E., Omed, H.M. (ed.). CABI Publishing. Wallingford. p. 175.188.

OUDE ELFERINK, S.J.W.H.; DRIEHUIS, F.; GOTTSCHAL, J.C. et al. Silage fermentation process and their manipulation. In: FAO ELETRONIC CONFERENCE OF TROPICAL SILAGES, Rome, 1999. Silage making in the tropics with emphasis on smallholders. Proceedings... Rome: FAO, 2000, p.17-30.

PAZIANI, S.F. Controle de perdas na ensilagem, desempenho e digestão de nutrientes em bovinos de corte alimentados com rações contendo silagens de capim tanzânia. Tese (Doutorado em Agronomia) - Escola Superior de Agricultura "Luiz de Queiroz", Universidade de São Paulo, Piracicaba. 208p., 2004.

PHILLIP, L.E.; FELLNER, V. Effects of bacterial inoculation of high-moisture ear corn on its aerobic stability, digestion, and utilization for growth by beef steers. Journal of Animal Science, v.70, n.10, p.3178-3187, 1992.

PLAYNE, M.J.; McDONALD, P. The buffering constituents of herbage and of silage. Journal of the Science of Food and Agriculture, v.17, p.264-268, 1966.

REIS, R.A.; COAN, R.M. Produção e utilização de silagens de gramíneas. In: SIMPÓSIO GOIANO SOBRE MANEJO E NUTRIÇÃO DE BOVINOS. Anais... Goiânia:CBNA, 2001, p.91-120.

RUPPEL, K.A.; PITT, R.E.; CHASE, L.E. et al. Bunker silo management and its relationship to forage preservation on dairy farms. Journal of Dairy Science, v.78, n.1, p.141-153, 1995.

SCHEMEL, H.; FÜRLL, C.H.; GLASER, M. et al. Density measurement on silage. In: Proceedings of the $12^{\text {th }}$ International Symposium Forage Conservation, BRNO, Czech Republic, 188-186, 2006.

SCHMIDT, P. Perdas fermentativas na ensilagem, parâmetros disgestivos e desempenho de bovinos de corte alimentados com rações contendo silagens de cana-de- 
açúcar. Piracicaba. Universidade de São Paulo, 2006. 228p. Tese (Doutorado em Agronomia). USP. Escola Superior de Agricultura Luiz de Queiroz. 2006.

SCHOCKEN-ITURRINO, R.P.; REIS, R.A.; COAN, R.M. et al. Alterações químicas e microbiológicas nas silagens de capim-Tiftoon 85 após a abertura dos silos. Revista Brasileira de Zootecnia, v.34, n.2, p.464-471, 2005.

SILVA, J.M.N. Desenvolvimento de microrganismos e valor nutritivo de silagens de capim-Tifton 85. Tese (Doutorado em Zootecnia) - Faculdade de Ciências Agrárias e Veterinárias, Universidade Estadual Paulista,Jaboticabal. 80p. , 2002.

SILVA, D.J.; QUEIROZ, A.C. Análise de Alimentos: métodos químicos e biológicos. 3.ed. Viçosa: UFV, 2002. 235p.

SILVA, M.O.S.A. Análises físico-químicas para controle de estação de tratamentos e esgotos. São Paulo, CETESB, 1977. 266p.

TENGERDY, R.P.; WEINBERG, Z.G.; SZAKACS, G. et al. Ensiling alfafa with additives of lactic acid bacteria and enzymes. Journal of the Science of Food and Agriculture, v.55, n.2, p.215-228, 1991.

TILLEY, J.M.A.; TERRY, R.A. A two stage technique for in vitro digestion of forages crops. Journal of the British Grassland Society, Aberystwyth, v. 18, p. 104-111, 1963. TOSI, H.; SCHOCKEN-ITURRINO, R.P.; RAVAZI, J.P. Presença de clostrideos em silagem de milho colhido em diferentes estádios de desenvolvimento. Pesquisa Agropecuária Brasileira, v.17, n.8, p.1133-1136, 1982.

UFRJ. <http://acd.ufrj.br/consumo/disciplina/cc_reduçaoaw. htm.> Acesso em: 15 mar. 2007.

VAN SOEST, P. Nutritional Ecology of the Ruminant. 2 ed. New york: Cornell university Press, 1994. 476p.

WARDYNSKI, F.A.; RUST, S.R.; YOKOYAMA, M.T. Effect of microbial inoculation of high-moisture corn in fermentation characteristics, aerobic stability, and cattle performance. Journal of Animal Science, v.71, p.2246-2252, 1993.

WILLIAMS, B.A. Cumulative gas-production techniques for forage evaluation. In: Forage Evaluation in Ruminant Nutrition. Givens, D.I., Owen, E., Axford, R.F.E., Omed, H.M. (ed.). CABI Publishing. Wallingford. p. 189-213. 2000. WILSON, R.F.; WILKINS, R.J. The ensilage of autumn-sown rye. Journal of British Grassland Society, v.27, p.35-41, 1972. 